\title{
Spatio-temporal pattern changes of land space in Hengduan Mountains during 1990-2015
}

\author{
SHI Zhenqin ${ }^{1,2},{ }^{*}$ DENG Wei ${ }^{1,2}$, ZHANG Shaoyao ${ }^{1,2}$ \\ 1. Institute of Mountain Hazards and Environment/Research Center for Mountain Development, CAS, \\ Chengdu 610041, China; \\ 2. University of Chinese Academy of Sciences, Beijing 100049, China
}

\begin{abstract}
Hengduan Mountains offer land space for a variety of ecological services. However, the sustainable development and management of land space has been challenged by increased human activities in recent years. This paper performs the spatial pattern analysis of the quantitative and structural changes of various landscapes at different altitudes, and uses the land use data in 1990, 2000, 2010 and 2015 to reveal how various land patterns have changed. The results show that, within the production-living-ecological space schema, the ecological space dominates Hengduan Mountains, while the production and living space was mainly distributed in south region. During 1990-2015, the production-living-ecological spatial changes had been gradually accelerated and the regional differences had become more prominent. The agricultural production space had continuously decreased by $1132.31 \mathrm{~km}^{2}$, and the industrial and mining production space had rapidly increased by $281.4 \mathrm{~km}^{2}$ during 1990-2015. The living space had steadily increased, and the ecological space had increased with fluctuations. The land space pattern in Hengduan Mountains was greatly restricted by the terrain, such as altitude and slope. The implementations of China Western Development Strategy and the Returning Farmland to Forest Program had favorably promoted the changes of land spatial pattern in Hengduan Mountains.
\end{abstract}

Keywords: land space, production-living-ecological space; spatio-temporal pattern; stepwise regression analysis; Hengduan Mountains

\section{Introduction}

China's land development is changing from production space-oriented alone to coordinated mode of production-living-ecological space development. Land use and cover change (LUCC) reflects the changes in spatial pattern due to coupled interactions between the human and environmental systems (Faludi et al., 2009; Fan et al., 2013; Pelucha et al., 2013). To optimize the land use, it is imperative to understand the evolution of ecosystems at geo-

Received: 2017-10-31 Accepted: 2017-12-20

Foundation: Major State Basic Research Development Program of China, No.2015CB452706

Author: Shi Zhenqin (1988-), PhD, specialized in regional development and land space management in mountain areas. E-mail: kevinszq@163.com

*Corresponding author: Deng Wei (1957-), Professor, specialized in mountain environment and regional development. E-mail: dengwei@imde.ac.cn 
graphical landscapes and at different economical levels and stages as a proportional measure of structure to functional space. Therefore, the analysis of land space pattern changes is very important for promoting orderly, moderate and sustainable development and utilization of land space.

The empirical methods of studying the production-living-ecological space can be divided into two types: top-down decomposition of functional space regionalization and bottom-up merge of land use classification (Huang et al., 2017). While the former is frequently used for qualitative analysis at the macro-scale of country, province and region, using administrative area as evaluation unit, the latter is used for quantitative analysis at the micro-scale of city, county, town and village, using land-use type as evaluation unit (Ma et al., 2015; Li et al., 2016; Xi et al., 2016). Although researchers have conducted comprehensive studies by combining these two methods, yet they have not formulated a study paradigm covering different scales with no consideration to land use type complexity limiting the production-livingecological space. Especially, there is little empirical research on the macro-scale production-living-ecological space in mountainous area (Zhang et al., 2015).

Mountain area is a special land space unit, with remote geographical location, large resource gradient, disaster proneness, ecological vulnerability, and other characteristics (Jansky et al., 2002). China is a mountainous country, which accounts for about $65 \%$ of the land area, and the population accounts for about $45 \%$ of the total (Deng et al., 2013). Unsustainable land space development in mountainous area has resulted in vegetation destruction, severe soil erosion, and land rocky desertification (Deng et al., 2013). In recent years, the rapid urbanization, industrialization, agricultural modernization, "help-the-poor" migration and disaster prevention relocation in mountainous area significantly brought changes in land spatial pattern, and put forward new challenges to the sustainable development and management of land space in mountainous area (Deng et al., 2015). Therefore, the study of the spatial pattern characteristics and land use changes in mountainous area has both theoretical and practical significance thereby providing guidelines for the development of land space in mountainous area. In this paper, we chose Hengduan Mountains, which encompass relatively complicated interactions between ecological environment and human society, to explore the spatio-temporal patterns and changes in land space usage in mountainous area in the past 25 years.

\section{Overview of research areas, data sources and research methods}

\subsection{Research areas}

Hengduan Mountains are located in the east of the Qinghai-Tibet Plateau, west of the Sichuan Basin and the northwest of the Yunnan-Guizhou Plateau. It is the transitional zone between the first and second ladder of Chinese terrain, with a total area of $449,841 \mathrm{~km}^{2}$, including some counties in Sichuan Province and Yunnan Province (Figure 1). Hengduan Mountains are a group of mountain ranges and valleys stretching from the north to the south. Within its territory, there are six water systems including the Salween, Lancang, Jinsha, Yalung, Dadu and Minjiang rivers. Hengduan Mountains with their soaring heights and deep valleys cover a wide range of altitude, which decreases from northwest to southeast, with the highest altitude of $7713 \mathrm{~m}$ and the lowest of $76 \mathrm{~m}$ (Figure 2). The research areas spanned 
over $10^{\circ}$ of latitude, with complex terrain and large temperature difference. It is controlled by the winter and summer monsoon circulations composed of the southeast monsoon, the southwest monsoon and the south branch of the westerly jet, throughout the year, and the precipitation contributes to seasonal changes (Li et al., 2010).

Hengduan Mountains play an important role in ecosystem services, including water conservation, climate regulation, soil and biodiversity conservation (Li et al., 2010). In 2010, the population in this area was 19.43 million, with a total gross national product of 313.20 billion yuan marked by accelerated population and economic growth. The conflict between the importance of an ecological space and the rapid socio-economic development in Hengduan Mountains has thus intensified ever since.

\subsection{Data sources}

The study utilized landsat TM5 with $30 \mathrm{~m}$ spatial resolution as data source of land use in 1990, 2000, 2010 and 2015, downloaded from the National

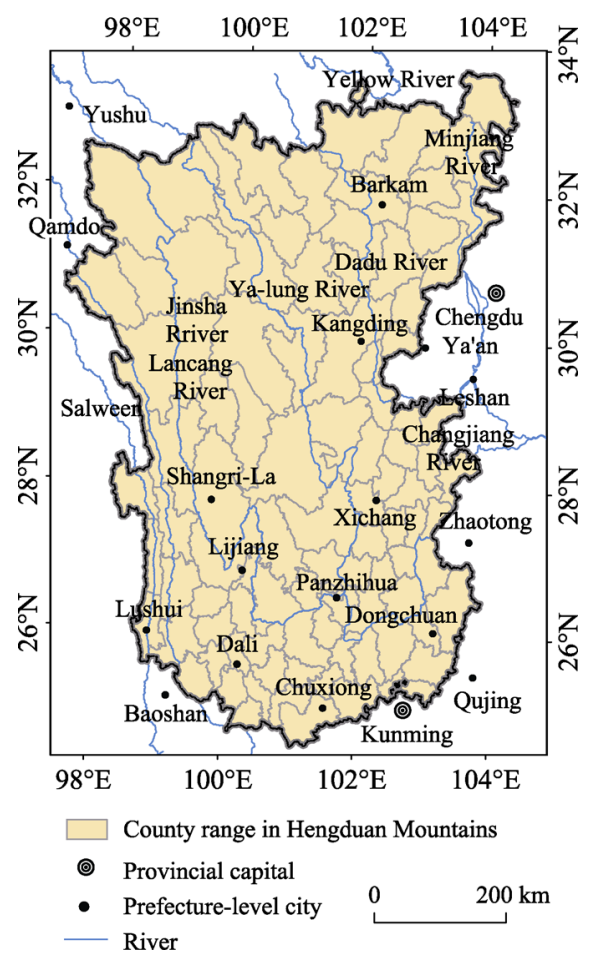

Figure 1 Location and area of Hengduan Mountains

Aeronautics and Space Administration (NASA) website (https://ecocast.arc.nasa.gov/ data/pub), to identify the production-living-ecological space in Hengduan Mountains. Because the landform complexity in mountainous area limited the production-living-ecological space pattern, we then used the DEM data with a resolution of $30 \mathrm{~m}$ to correct the effect of slope, and recalculated the slope area.

\subsection{Research methods}

Using the methods of dynamics, conversion matrix of land use and landscape pattern index, to summarize the horizontal and vertical gradient of the production-living-ecological space pattern in Hengduan Mountains, analyze the areal, structural, interchanges within landscape patterns, and explore the spatial difference of the production-living-ecological space (Cai et al., 2006; Peng et al., 2006; Liu et al., 2010). The standard deviational ellipse (Wang et al., 2014; Huo et al., 2016) was used to analyze the directional expansion of living space, and to reveal the tendency of land space pattern changes in Hengduan Mountains from 1990 to 2015. We also quantitatively study the natural and humanistic driving factors of spatio-temporal patterns and changes in land, by using the multi-step progressive regression to analyze

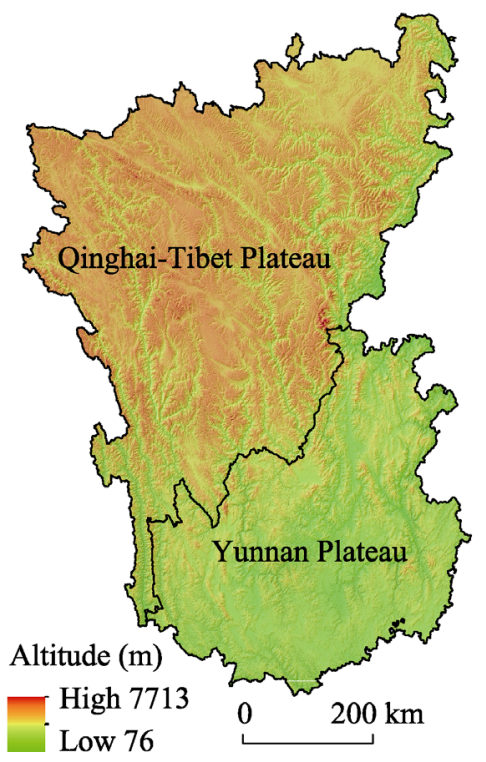

Figure 2 Hengduan Mountains terrain map 
the natural factors extracted by DEM data, and the counties' panel data (Chen et al., 2014; Zhang et al., 2016).

\section{The production-living-ecological land space classification system}

China's land classification system is based on the status of land use (Blum, 1998; Banko et al., 2001; Zhou, 2004; Fang et al., 2008; Fleskens et al., 2009). Currently, the wide used system is the second national land use survey classification of China (http://www.mlr.gov.cn/) and the land use and land cover classification system of Chinese Academy of Sciences.

The versatility of land is an important foundation for sustainable development, and the classification of the production-living-ecological space is based on the functional classification of land use (Kates et al., 2001; Chen et al., 2005; Marsden et al., 2008; Liu et al., 2010). In this paper, we gave consideration to the spatial versatility of land, the central position of ecological function and the classification principle of considering main function, and established the relationship between the production-living-ecological land space classification system and the classification based on present land use in mountainous areas (Table 1).

Table 1 Connection between the classification system of territory space and land use

\begin{tabular}{|c|c|c|c|}
\hline $\begin{array}{l}\text { The produc- } \\
\text { tion-living-ecolo } \\
\text { gical land space } \\
\text { classification }\end{array}$ & $\begin{array}{l}\text { The production-living- } \\
\text { ecological land space, } \\
\text { secondary } \\
\text { classification }\end{array}$ & $\begin{array}{l}\text { Second national land survey } \\
\text { classification }\end{array}$ & $\begin{array}{c}\text { Chinese Academy of Sciences } \\
\text { land classification }\end{array}$ \\
\hline \multirow{3}{*}{$\begin{array}{l}\text { Production } \\
\text { space }(\mathrm{PP})\end{array}$} & $\begin{array}{l}\text { Agricultural produc- } \\
\text { tion space (APS) }\end{array}$ & $\begin{array}{l}011 \text { paddy field, } 012 \text { irrigated } \\
\text { field, } 013 \text { dry land, } 021 \text { orchard, } \\
022 \text { tea garden, } 023 \text { other fields, } \\
104 \text { rural road, } 122 \text { agricultural } \\
\text { facility land, } 123 \text { field ridge }\end{array}$ & \multirow{3}{*}{53 other construction field } \\
\hline & $\begin{array}{l}\text { Industrial and min- } \\
\text { ing production space } \\
\text { (IMPS) }\end{array}$ & $\begin{array}{l}061 \text { industrial field, } 062 \text { mining } \\
\text { field, } 063 \text { warehouse field, } 101 \\
\text { railroad field, } 102 \text { highway land, } \\
105 \text { airport land, } 106 \text { port and } \\
\text { dock land, } 107 \text { pipeline trans- } \\
\text { portation land, } 118 \text { waterwork } \\
\text { field, } 204 \text { mining field }\end{array}$ & \\
\hline & $\begin{array}{l}\text { Service production } \\
\text { space(SPS) }\end{array}$ & $\begin{array}{l}088 \text { scenic site facility field, } 205 \\
\text { scenic site and special field }\end{array}$ & \\
\hline \multirow{2}{*}{$\begin{array}{l}\text { Living space } \\
\text { (LP) }\end{array}$} & $\begin{array}{l}\text { City and town living } \\
\text { space (CTLS) }\end{array}$ & $\begin{array}{l}201 \text { city, } 202 \text { organizational town, } \\
103 \text { street and lane field, } 087 \\
\text { park and green land, } 21 \text { idle land }\end{array}$ & 51 city and town land \\
\hline & $\begin{array}{l}\text { Rural living space } \\
\text { (RLS) }\end{array}$ & $\begin{array}{l}203 \text { village, } 072 \text { rural residential } \\
\text { land }\end{array}$ & 52 rural residential area land \\
\hline \multirow{3}{*}{$\begin{array}{l}\text { Ecological } \\
\text { space (EP) }\end{array}$} & $\begin{array}{l}\text { Green ecological } \\
\text { space (GES) }\end{array}$ & $\begin{array}{l}031 \text { forest land, } 032 \text { shrub land, } \\
033 \text { other woodland, } 041 \text { natural } \\
\text { grassland, } 042 \text { artificial grass- } \\
\text { land, } 043 \text { other grassland }\end{array}$ & $\begin{array}{l}21 \text { forest land, } 22 \text { shrub } \\
\text { land, } 23 \text { sparse woodland, } \\
24 \text { other woodland, } 31 \text { high } \\
\text { coverage grassland, } 32 \text { me- } \\
\text { dium coverage grassland, } 33 \\
\text { low coverage grassland }\end{array}$ \\
\hline & $\begin{array}{l}\text { Water ecological } \\
\text { space (WES) }\end{array}$ & $\begin{array}{l}111 \text { river surface, } 112 \text { lake surface, } \\
113 \text { water reservoir surface, } 114 \\
\text { pit and pod surface, } 115 \text { coastal } \\
\text { shoal, } 116 \text { inland shoal, } 119 \\
\text { glacier and firn, } 125 \text { swampland }\end{array}$ & $\begin{array}{l}41 \text { river and canal, } 42 \text { lake, } \\
43 \text { water reservoir, pit and } \\
\text { pod, } 44 \text { glacier and firn, } 45 \\
\text { sea shoal, } 46 \text { beach land }\end{array}$ \\
\hline & $\begin{array}{l}\text { Other ecological } \\
\text { space (OES) }\end{array}$ & $\begin{array}{l}124 \text { saline and alkaline land, } 126 \\
\text { sandy land, } 127 \text { bare land }\end{array}$ & $\begin{array}{l}1 \text { sandy land, } 62 \text { saline and } \\
\text { alkaline land, } 64 \text { marshland, } \\
65 \text { bare land, } 66 \text { bare rock } \\
\text { land, } 67 \text { others }\end{array}$ \\
\hline
\end{tabular}




\section{Characteristics of the production-living-ecological space patterns}

\subsection{Characteristics of horizontal space}

In Hengduan Mountains, the ecological space was the absolute subject, which accounts for $92.53 \%$ of the total area. The relief affects land pattern in Hengduan Mountains significantly, the north part has high altitude, is mostly the ecological space, the production and living space are mainly distributed in Yunnan, highly concentrated in Liangshan Yi Autonomous Prefecture, Lijiang, Dali, Panzhihua city and Chuxiong Yi Autonomous Prefecture (Figure 3).

\subsection{Vertical gradient features}

The largest land area of Hengduan Mountains is at elevation belt of 4000-4500 m, followed by $3500-4000 \mathrm{~m}$, and again $2000-2500 \mathrm{~m}$. At the elevation belt of $3000-3500 \mathrm{~m}$, the total land area is greatly reduced. With increasing altitude, agricultural production space (APS) area increases first and then decreases, the peaks at the altitude range of 1500-2000 m, and the percentage $(58.60 \%)$ peaks at the altitude range less than $1000 \mathrm{~m}$. Similarly, the living space (LP) area increases with elevation, increasing first and then decreasing, and urban and rural living space area values both peak at the altitude range of 1500-2000 m. The maximum of percentage value of urban living space is at the altitude range of 1000-1500 m, while that of rural living space (RLS) is at the altitude range of 1500-2000 m. The vertical structure characteristics of the land space in Hengduan Mountains suggest that the ecosystem is fragile.

\section{The change of production-living-ecological space patterns}

\subsection{Quantitative structure change}

From 1990 to 2015, the production space in Hengduan Mountains had continuously decreased, otherwise the living space gradually increased, and the ecological space had fluctuated (Table 2). The decrease in agricultural production space had ranged between 195.60 to $1132.31 \mathrm{~km}^{2}$, at altitude of $1200-1400 \mathrm{~m}$, which accounts for $12 \%$ of the total agricultural production space at this region (Figure 5). Industrial and mining production space had gradually increased, significantly from 2000 to 2010, with an annual increase of $35.14 \%$ (Table 3). The living space in both urban and rural areas had gradually increased by 188.71 $\mathrm{km}^{2}$ and $168.87 \mathrm{~km}^{2}$, respectively. The increase of urban living area was higher than that of rural area, the green ecological space increased by $1632.67 \mathrm{~km}^{2}$ and the water ecological space decreased by $281.88 \mathrm{~km}^{2}$. The changes in the production-living-ecological spatial patterns had gradually accelerated, and the regional differences had been more prominent. The industrial and mining production space, city and town living space, water ecological space of the northern part had shown rapid growth from 2000 to 2010 .

There are obvious spatial differences in the changes of production-living-ecological space area in Hengduan Mountains from 1990 to 2015 (Figure 6). Among total 99 county-level administrative units, agricultural production space area of 78 counties has decreased, the counties with significant increase in agricultural production space area were concentrated in the northeast of Hengduan Mountains. The counties with increased living space area were concentrated in the south, and the counties with decreased living space area were mostly 
(a) 1990

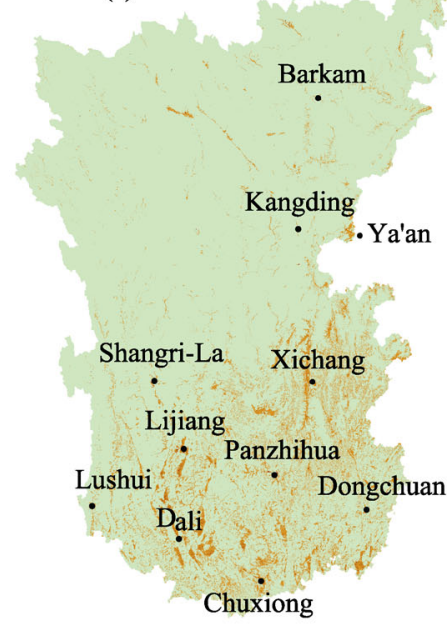

(c) 2010 (b) 2000

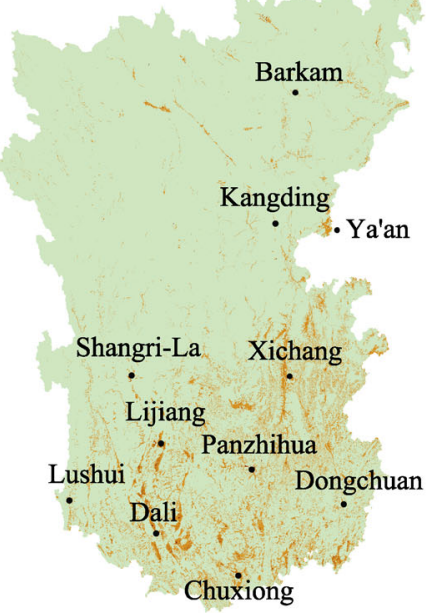

(d) 2015
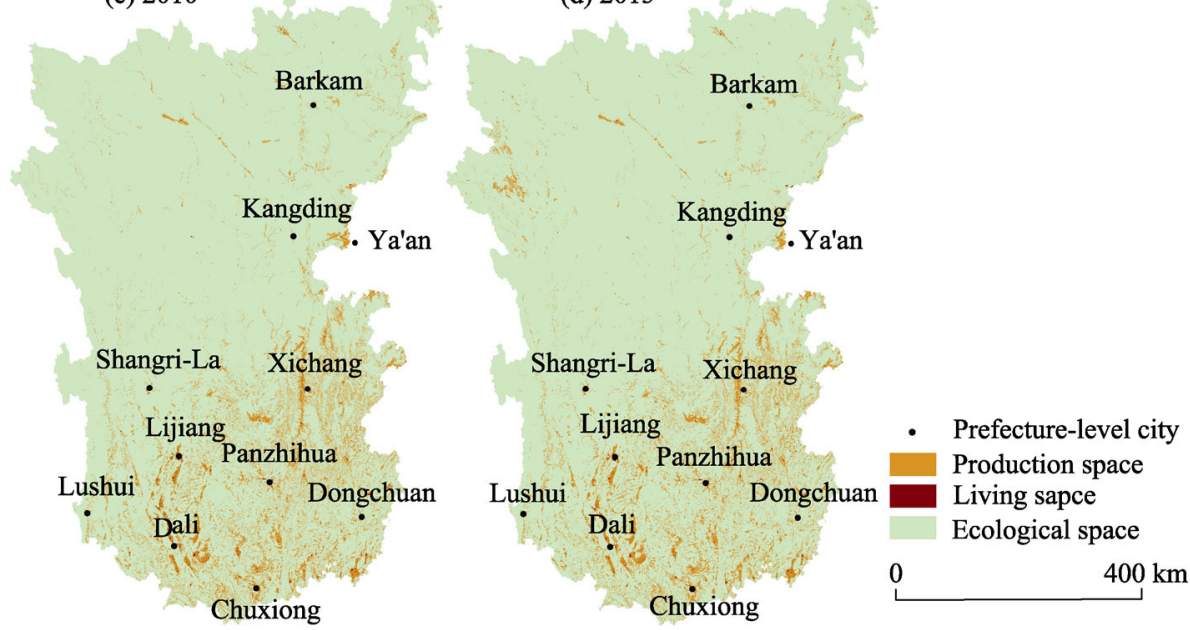

Figure 3 The production-living-ecological space pattern of Hengduan Mountains in four periods of time (a. 1990; b. 2000; c. 2010; d. 2015)

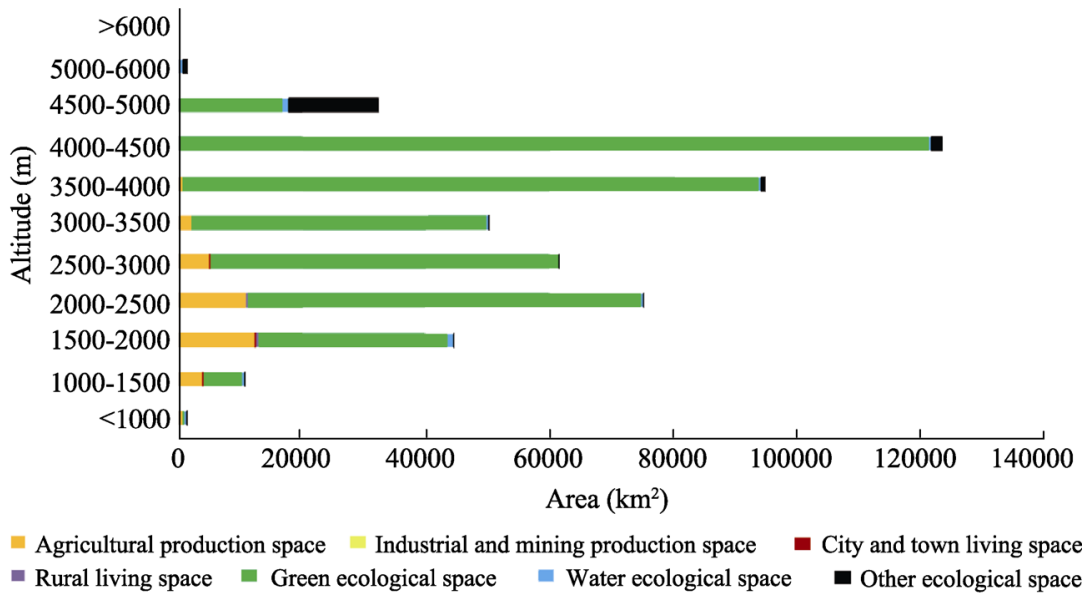

Figure 4 The changes of production-living-ecological space area at different altitudes 
concentrated in the northwest. The area of ecological space in 64 counties increased, the counties with significant decrease in ecological space were mainly concentrated in the northeast. The counties with decreased agricultural production space area have consistency to that with increased ecological space area. In general, there are significant regional differences in compositional changes of the production-living- ecological space in past 25 years. The agricultural production space and living space has decreased and the ecological space increased in the northwest; the agricultural production space and living space has increased and the ecological space significantly reduced in the northeast; the agricultural production space has decreased, living and ecological space increased in the southwest; the agricultural production and ecological space decreased, and the living space has increased in the southeast.

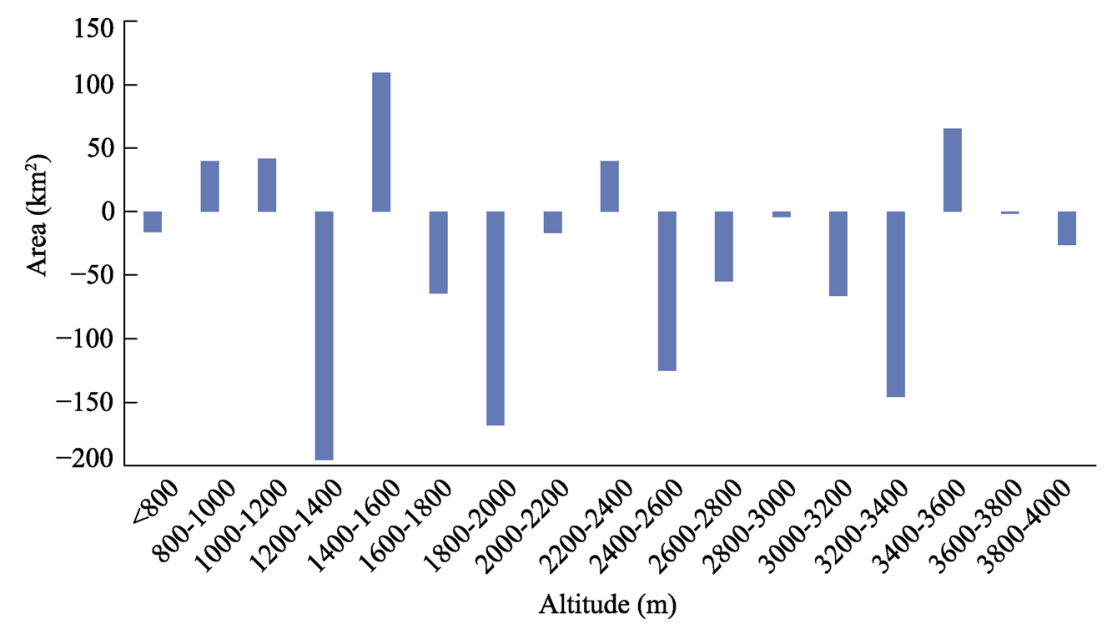

Figure 5 Area changes of agricultural production space each at $200 \mathrm{~m}$ altitude

Table 3 Annual changes of the ecological-production-living space from 1990 to 2010 (\%)

\begin{tabular}{|c|c|c|c|c|c|c|}
\hline \multirow[b]{2}{*}{ Space type } & \multicolumn{3}{|c|}{$1990-2000$} & \multicolumn{3}{|c|}{$2000-2010$} \\
\hline & All & $\begin{array}{l}\text { Qinghai-Tibet } \\
\text { Plateau }\end{array}$ & $\begin{array}{l}\text { Yunnan } \\
\text { plateau }\end{array}$ & All & $\begin{array}{l}\text { Qinghai-Tibet } \\
\text { Plateau }\end{array}$ & $\begin{array}{l}\text { Yunnan } \\
\text { plateau }\end{array}$ \\
\hline Agricultural production space & -0.07 & 0.14 & -0.11 & -0.06 & 0.30 & -0.13 \\
\hline $\begin{array}{l}\text { Industrial and mining produc- } \\
\text { tion space }\end{array}$ & 0.49 & 4.83 & 0.39 & 35.14 & 239.43 & 28.70 \\
\hline City and town living space & 4.65 & 1.32 & 5.43 & 5.52 & 8.54 & 5.01 \\
\hline Rural living space & 0.51 & 0.06 & 0.57 & 1.41 & 2.53 & 1.27 \\
\hline Green ecological space & 0.01 & -0.01 & 0.05 & -0.01 & -0.02 & 0.00 \\
\hline Water ecological space & -1.27 & 0.24 & -2.38 & 3.36 & 6.49 & 0.26 \\
\hline Other ecological space & 0.11 & 0.11 & -0.05 & -0.28 & -0.30 & 0.26 \\
\hline
\end{tabular}

\subsection{The interchange of the production-living-ecological space}

The spatial change of the land in Hengduan Mountains is not only reflected in the quantitative structure, but also reflected in the mutual conversion of different land space types. The 
(a) Agricultural production space

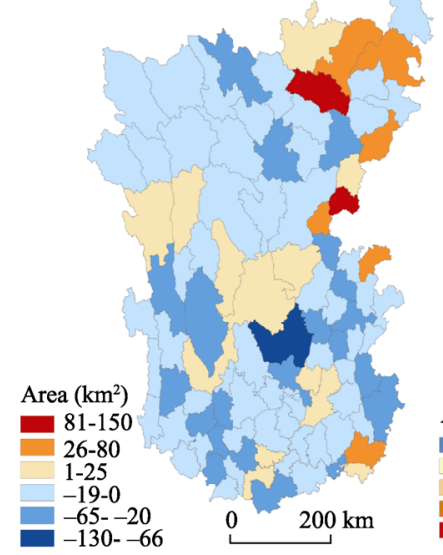

(b) Living space

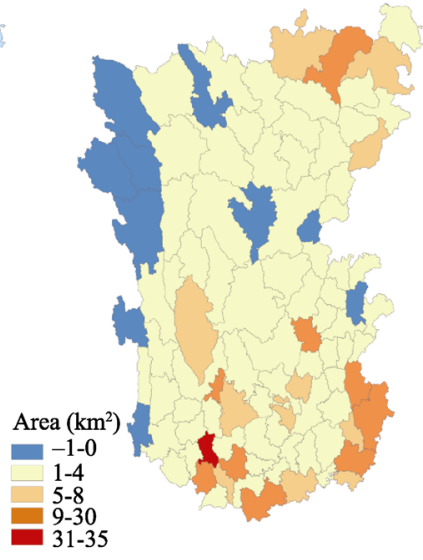

(c) Ecological space

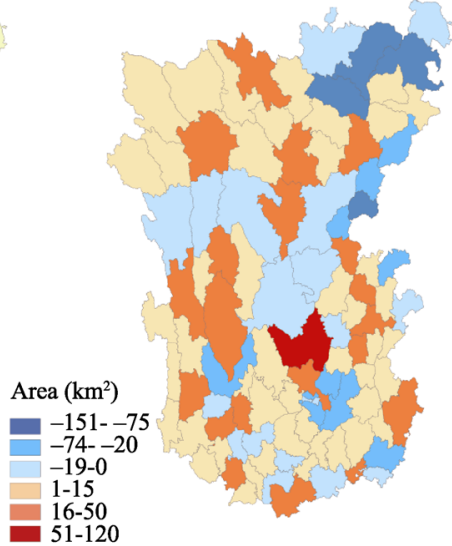

Figure 6 The difference of spatial change of the production-living-ecological space from 1990 to 2015 (a. agricultural production space; b. living space; c. ecological space)

conversion matrix shows that the agricultural production space was greatly reduced from 1990 to 2015, and the interchange amount with green ecological space was the highest, $339.52 \mathrm{~km}^{2}$. Both industrial and mining production space and urban and rural living space increased mainly due to decrease of green ecological and agricultural production space. Mild increase in the green ecological space was mainly from the conversion from agricultural production and other ecological space. The water ecological space slightly decreased as it mainly transformed into green ecological space; other ecological space was also significantly reduced by $2748.55 \mathrm{~km}^{2}$ (Table 4). The scale of land transfer in 1990-2000 (Table 5) is far less than that in 2000-2010 (Table 6).

Table 4 Conversion matrix of land space of Hengduan Mountains from 1990 to $2015\left(\mathrm{~km}^{2}\right)$

\begin{tabular}{cccccccc}
\hline \multirow{2}{*}{ Year 2015 } & \multicolumn{7}{c}{ Year 1990 } \\
\cline { 2 - 8 } & APS & IMPS & CTLS & RLS & GES & WES & OES \\
\hline APS & 28520.12 & 12.57 & 8.11 & 188.09 & 6495.86 & 128.81 & 20.75 \\
IMPS & 123.67 & 41.33 & 0.63 & 2.52 & 175.78 & 2.18 & 0.78 \\
CTLS & 168.31 & 0.36 & 121.63 & 6.53 & 29.24 & 1.96 & 0.38 \\
RLS & 156.43 & 1.77 & 0.97 & 349.26 & 72.61 & 8.11 & 0.17 \\
GES & 6835.38 & 4.07 & 5.33 & 46.93 & 422397.51 & 921.09 & 6108.36 \\
WES & 200.87 & 1.44 & 0.89 & 4.15 & 615.26 & 2214.58 & 43.71 \\
OES & 20.28 & 0.00 & 0.60 & 2.71 & 3264.26 & 31.32 & 13292.07 \\
\hline
\end{tabular}

Table 5 Conversion matrix of land space area of Hengduan Mountains from 1990 to $2000\left(\mathrm{~km}^{2}\right)$

\begin{tabular}{|c|c|c|c|c|c|c|c|}
\hline \multirow{2}{*}{ Year 2000} & \multicolumn{7}{|c|}{ Year 1990} \\
\hline & IPS & IMPS & CTLS & RLS & GES & WES & OES \\
\hline APS & 35702.76 & 0.08 & 0.41 & 3.25 & 475.13 & 28.88 & 0.96 \\
\hline IMP & 4.94 & 47.35 & 0.00 & & 12.83 & & \\
\hline CTLS & 61.64 & & 136.97 & 1.49 & 4.02 & 0.30 & \\
\hline RLS & 26.00 & & 1.57 & 609.55 & 4.17 & 7.12 & \\
\hline GES & 622.08 & 1.00 & 0.08 & 1.10 & 433296.83 & 574.62 & 237.20 \\
\hline WES & 56.45 & 13.68 & 0.44 & 1.66 & 102.61 & 2744.67 & 11.91 \\
\hline OES & 0.00 & & & & 460.01 & 1.72 & 19252.74 \\
\hline
\end{tabular}


Table 6 Conversion matrix of land space area of Hengduan Mountains from 2000 to $2010\left(\mathrm{~km}^{2}\right)$

\begin{tabular}{|c|c|c|c|c|c|c|c|}
\hline \multirow{2}{*}{ Year 2010} & \multicolumn{7}{|c|}{ Year 2000} \\
\hline & APS & IMPS & CTLS & RLS & GES & WES & OES \\
\hline APS & 33932.62 & 2.97 & 14.75 & 25.87 & 1985.39 & 36.41 & 8.39 \\
\hline IMPS & 94.98 & 51.44 & 1.95 & 1.82 & 138.56 & 4.53 & 0.74 \\
\hline CTLS & 110.93 & 0.09 & 177.82 & 6.70 & 21.09 & 0.55 & 0.18 \\
\hline RLS & 92.42 & 1.88 & 2.80 & 591.34 & 49.54 & 1.51 & 0.06 \\
\hline GES & 1896.59 & 8.00 & 5.47 & 14.92 & 429574.16 & 139.79 & 2567.86 \\
\hline WES & 73.38 & 0.62 & 0.94 & 4.69 & 641.53 & 2744.57 & 453.11 \\
\hline OES & 16.64 & 0.10 & 0.70 & 3.09 & 2444.73 & 4.90 & 16686.88 \\
\hline
\end{tabular}

\subsection{Changes in landscape pattern}

The analysis of landscape pattern index based on data of land use and cover is an important method for the study of landscape pattern (Ma et al., 2000). In this paper, we chose a total of 5 landscape indices: the number of patches (NP), the mean patch space (MPS), landscape contagion index (CONTAG), Shannon evenness index (SHEI) and Shannon diversity index (SHDI), to analyze landscape fragmentation, connectivity, dominance and diversity of the production-living-ecological space in Hengduan Mountains, and to interpret the changing process of the landscape pattern of production-living-ecological space from 1990 to 2015 (Zhou et al., 2012).

Firstly, the number of landscape patches in Hengduan Mountains had decreased, and the mean patch space increased slightly from 1990 to 2000, then the number of landscape patches increased rapidly from 46947 to 57653 , and the mean patch space reduced from $957 \mathrm{~m}^{2}$ to $777 \mathrm{~m}^{2}$ during the period 2000-2015. It was mainly caused by an aggregate growth of 1.79 million permanent resident population in the same period. Thus, the conversion between the landscape increased significantly, and the landscape pattern was more fragmented. Secondly, the landscape contagion index variation increased, meaning the overall landscape connectivity was enhanced. Thirdly, the Shannon evenness index variation decreased, and the landscape dominance increased slightly. The Shannon diversity index variation decreased, slightly increasing from 2000 to 2010 and decreasing rapidly from 0.490 to 0.472 from 2010 to 2015 with a decrease in the overall landscape diversity (Figure 7).

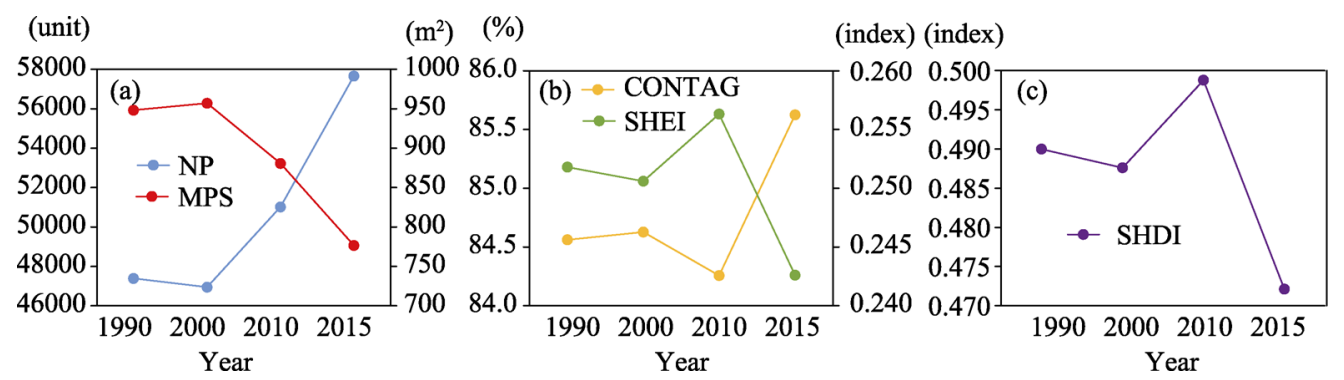

Figure 7 Landscape pattern index variation of territorial space in Hengduan Mountains

\subsection{Changes in living space pattern}

The data for spatial expansion research were mainly derived from remote sensing image (Li 
et al., 1997; Zeng et al., 2012). However, the boundary of city and town living space is indistinct, and the changes between patches are not clear. Therefore, the point pattern analysis method that originated in plant ecology has been more applied to the study of spatial expansion (Ersbøll et al., 2009). Due to the unique complexity of the mountain, the difference of geographical phenomena spatial dispersion becomes more significant in all directions. The standard deviational ellipse of the point pattern analysis (PPA) methods can better analyze the spatial expansion characteristics in each direction. Therefore, we used the Directional Distribution (Standard Deviational Ellipse) tool in ArcMap of ArcGIS software, to establish the standard deviational ellipses of living space in Hengduan Mountains in four periods, and based on the three parts of calculation results of standard deviational ellipse, we analyzed the difference of living space pattern changes in all directions (Zhao et al., 2012).

The living space pattern of Hengduan Mountains changed slightly from 1990 to 2000, but the elliptical area of standard deviation increased significantly and the living space expanded rapidly from 2000 to 2015 (Table 7).

Table 7 The parameters of standard deviational ellipse of the living space pattern in Hengduan Mountains

\begin{tabular}{ccccc}
\hline Year & Area $\left(\mathrm{km}^{2}\right)$ & $\mathrm{X}$ axis standard deviation $(\mathrm{km})$ & Y axis standard deviation $(\mathrm{km})$ & Rotation angle $\left({ }^{\circ}\right)$ \\
\hline 1990 & 139494.08 & 150.21 & 295.62 & 7.09 \\
2000 & 139297.11 & 150.26 & 295.1 & 7.36 \\
2010 & 145819.36 & 151.76 & 305.88 & 7.51 \\
2015 & 150733.23 & 156.95 & 306.74 & 7.61 \\
\hline
\end{tabular}

The increase in the standard deviation of $\mathrm{Y}$ axis was higher than that of $\mathrm{X}$ axis, and the increase in $\mathrm{Y}$ axis was more prominent, which indicated that the living space of Hengduan Mountains expanded rapidly along the $\mathrm{Y}$ axis direction, i.e., the northeast direction. As the elliptical rotation angle gradually increased, the living space formed of north-south spatial pattern, Chengdu, Kunming and other regional central cities had clearly attracted the extension and expansion of living space of Hengduan Mountains in their directions (Figure 8).

\section{The driving factors of land space change}

\subsection{Natural factors}

The formation and change of land space was the result of interaction between natural and humanistic factors. Therefore, altitude $\left(X_{1}\right)$, slope $\left(X_{2}\right)$, relief $\left(X_{3}\right)$ were extracted from

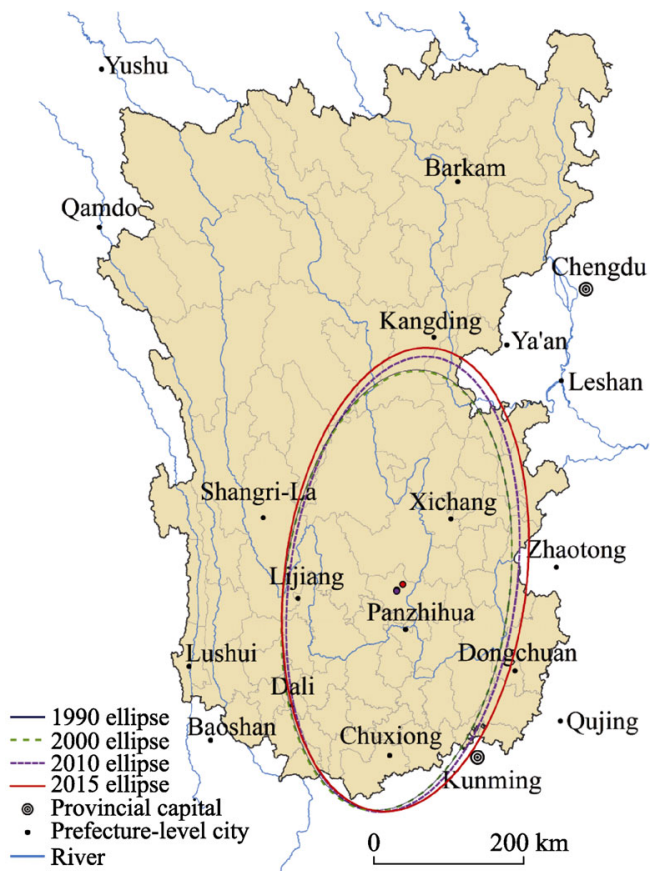

Figure 8 Change in standard deviational ellipse of living space in Hengduan Mountains 
the DEM, annual precipitation $\left(X_{4}\right)$ and average temperature $\left(X_{5}\right)$ were gained from China meteorological science data sharing service platform (http://data.cma.cn/), for the purpose to explore the effects of natural factors on agricultural production space and living space area. Results showed that the agricultural production space and living space area in Hengduan Mountains mostly distributed in the area where the altitude is below $3500 \mathrm{~m}$, the slope less than $28^{\circ}$, the relief is less than $5000 \mathrm{~m}$, where the annual precipitation is $700-1100 \mathrm{~mm}$.
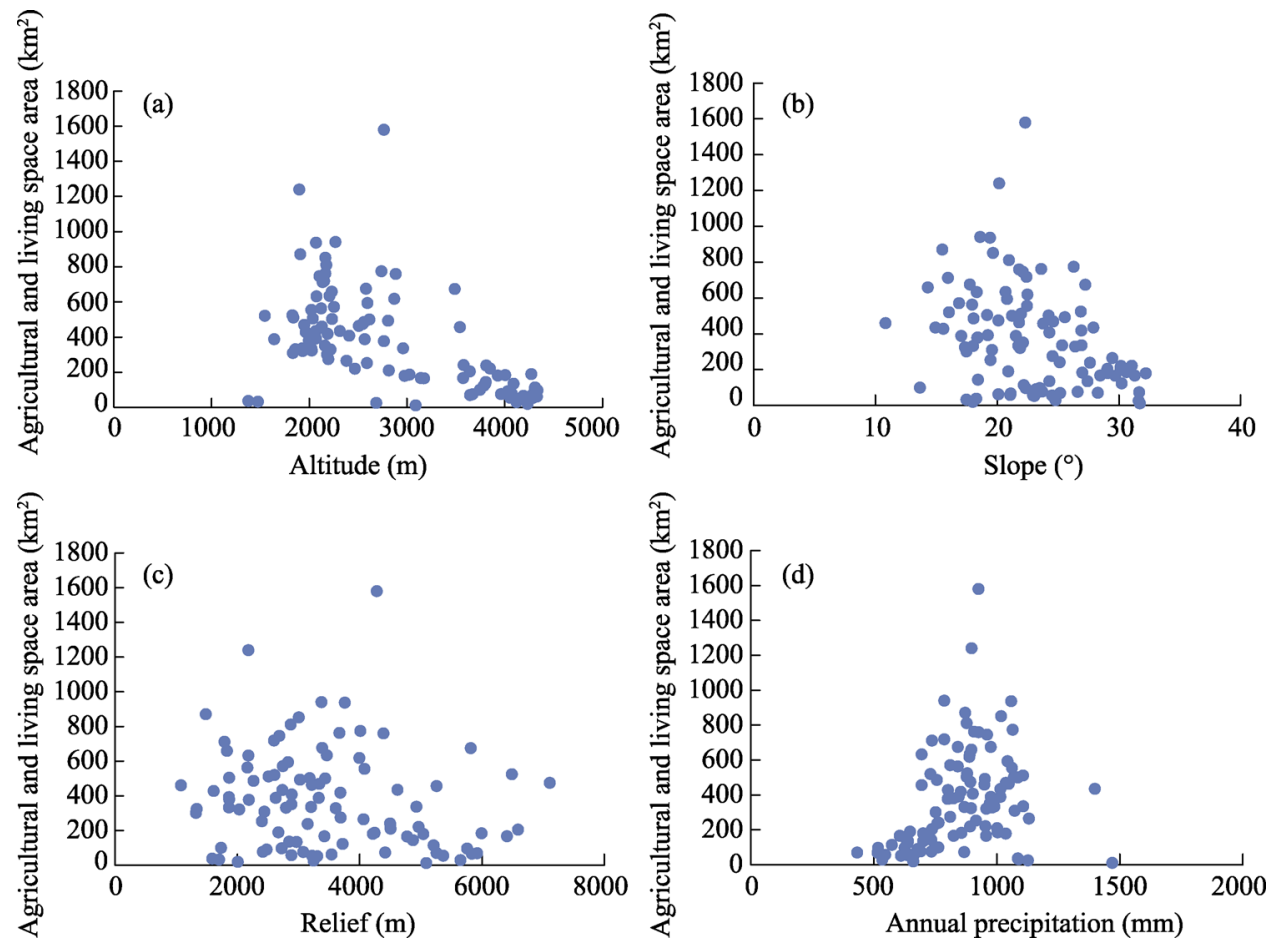

Figure 9 Relationship among natural elements, agricultural production and living space in Hengduan Mountains in 2010 (a. altitude; b. slope; c. relief; d. annual precipitation)

\subsection{Human factors}

Apart from natural factors, GDP $\left(X_{6}\right)$, permanent residents $\left(X_{7}\right)$, population density $\left(X_{8}\right)$, the urbanization rate $\left(X_{9}\right)$, urban employment rate $\left(X_{10}\right)$, rural employment rate $\left(X_{11}\right)$, per capita net income of rural residents $\left(X_{12}\right)$ and urban residents $\left(X_{13}\right)$, grain yield $\left(X_{14}\right)$, the whole society fixed asset investment $\left(X_{15}\right)$, location advantage $\left(X_{16}\right)$, road network density $\left(X_{17}\right)$ and other indicators were taken into the multiple stepwise regression, to explore the affecting factors of agricultural production space $\left(Y_{1}\right)$ and living space $\left(Y_{2}\right)$ change.

According to stepwise regression results, the affecting factors of agricultural production space change could be expressed as follows.

$$
Y_{1}=0.003 X_{14}-0.081 X_{1}-7.25 X_{17}+433.936
$$

where $X_{14}$ is the first independent variable introduced into the stepwise regression model, followed by $X_{1}$ and $X_{17}$ at county level. $X_{14}$ and production space are significantly correlated, meaning the increase of grain yield $\left(X_{14}\right)$ would encouraged farmers to explore farmland in Hengduan Mountains, where agricultural production is the main income. $X_{1}$ and $X_{17}$ are significantly negatively correlated with agricultural production space, because the increase of 
road network density $\left(X_{17}\right)$ would lead residents to expand their living space but encroached the agricultural production space.

In the same way, the regression model of affecting factors of living space is as below.

$$
Y_{2}=0.0004 X_{7}-0.6 X_{2}+1.941 X_{10}-0.033 X_{8}+0.902 X_{17}+0.001 X_{13}-1.899
$$

Independent variables that permanent residents $\left(X_{7}\right)$, slope $\left(X_{2}\right)$, urban employment rate $\left(X_{10}\right)$, population density $\left(X_{8}\right)$, road network density $\left(X_{17}\right)$, and per capita net income of urban residents $\left(X_{13}\right)$ were introduced into the stepwise regression model (Table 9). $X_{7}, X_{10}, X_{17}$, and $X_{13}$ are significantly positively related to living space. Since the large amount of population of permanent residents and urban employment increased demand for living space, and the raising road network density and ascension of urban residents' disposable income provided convenient traffic and economic foundation for living space expansion. Both $X_{2}$ and $X_{8}$ have negatively correlated with living space. Living space in the northern Hengduan Mountains mostly located in the low altitude valleys, where both terrain conditions and feature of disaster avoidance are of benefit to living space expansion.

Table 8 Coefficients of the production space regression model in Hengduan Mountains in 2010

\begin{tabular}{lccccc}
\hline \multirow{2}{*}{ Variable } & \multicolumn{2}{c}{ Unstandardized coefficient } & Standardized coefficient & \multirow{2}{*}{$\mathrm{t}$} & Sig. \\
\cline { 2 - 5 } & $\mathrm{B}$ & Std. Error & $\mathrm{Beta}$ & & \\
\hline Grain yield & 0.003 & 0.000 & 0.705 & 10.731 & 0.000 \\
Elevation & -0.081 & 0.023 & -0.252 & -3.457 & 0.001 \\
Road network density & -7.250 & 2.289 & -0.192 & -3.167 & 0.002 \\
(Constant) & 433.936 & 86.152 & & 5.037 & 0.000 \\
\hline
\end{tabular}

Notes: Dependent Variable: Production space areas $\mathrm{R}^{2}=0.729 \quad$ Adjusted $\mathrm{R}^{2}=0.721$

Table 9 Coefficients of the living space regression model in Hengduan Mountains in 2010

\begin{tabular}{cccccc}
\hline Variable & \multicolumn{2}{c}{ Unstandardized coefficient } & Standardized coefficient & \multirow{2}{*}{ S } & Sig. \\
\cline { 2 - 5 } & $\mathrm{B}$ & Std. Error & Beta & & \\
\hline Permanent residents & 0.00004 & 0.000 & 0.461 & 5.523 & 0.000 \\
Slope & -0.600 & 0.189 & -0.215 & -3.177 & 0.002 \\
Urban employment rate & 1.941 & 0.960 & 0.256 & 2.022 & 0.046 \\
Population density & -0.033 & 0.007 & -0.627 & -4.452 & 0.000 \\
Road network density & 0.902 & 0.322 & 0.504 & 2.801 & 0.006 \\
Urban per capita disposable income & 0.001 & 0.000 & 0.130 & 2.111 & 0.037 \\
(Constant) & -1.899 & 9.935 & & -0.191 & 0.849
\end{tabular}

Notes: Dependent Variable: Living space areas $\mathrm{R}^{2}=0.732 \quad$ Adjusted $\mathrm{R}^{2}=0.715$

\section{Conclusions}

We used the land use data of Hengduan Mountains in 1990, 2000, 2010 and 2015 to perform the spatial pattern analysis of the quantitative and structural changes of various landscapes at different altitudes and revealed the distribution of land pattern changes from 1990 to 2015 .

(1) Hengduan Mountains have relatively high altitude and significant vertical difference. The area of land space at the altitude belt of $4000-4500 \mathrm{~m}$ is the largest (24.93\%), followed by 3500-4000 $\mathrm{m}$ (19.15\%). 
(2) The ecological space is of absolute importance in the production-living-ecological space system in Hengduan Mountains. The pattern of land space is mainly affected by its terrain. While ecological space absolutely dominates the northern region, the production and living space is mainly distributed in the southeastern Yunnan.

(3) The production space in Hengduan Mountains has continuously decreased, the living space has gradually increased and the ecological space fluctuated from 1990 to 2015. The spatial change of the production-living-ecological spaces has gradually increased, and the regional difference has been more prominent. During the period 2000-2010, the area of industrial and mining production space, the city and town living space, and water ecological space in north region has rapidly increased by $47.66 \mathrm{~km}^{2}, 25.38 \mathrm{~km}^{2}$ and $946.62 \mathrm{~km}^{2}$, respectively. The fragmentation and connectivity of landscape has increased, the landscape dominance has increased slightly, and the diversity has decreased.

(4) Land pattern in Hengduan Mountains is restricted by natural factors. According to this research, marginal value for agricultural production space and living space was that altitude of $3500 \mathrm{~m}$, slope of $28^{\circ}$, relief of $5000 \mathrm{~m}$, and annual precipitation of $700 \mathrm{~mm}$. At county scale, both elevation and slope are the main restricting factors for agricultural production and living space. Besides, grain yield, the density of road network are the main human factors affecting agricultural production space, and the population of permanent residents, urban employment rate, population density, the density of road network, and urban residents' disposable income as the main human factors affecting living space.

\section{References}

Banko G, Mansberger R, 2001. Assessment of 'Non monetary value of land' for natural resources management using spatial indicators. International Conference on Spatial Information for Sustainable Development, Nairobi, $2-5$.

Blum W E H, 1998. Methods for Assessment of Soil Degradation. New York: CRC Press.

Chen Cong, Liu Yansui, 2014. The spatio-temporal patterns of urbanization of China's agricultural area and its influential factors: The case of Henan Province. Economic Geography, 34(12): 48-54. (in Chinese)

Chen Jing, Shi Peijun, 2005. Discussion on functional land use classification system. Journal of Beijing Normal University, 41(5): 536-540. (in Chinese)

Cai Weimin, Tang Huajun, Lv Gang et al., 2006. Application of approach of landscape pattern analysis and land use conversion matrix in research of land use characteristics. China Land Science, 20(1): 39-44. (in Chinese)

Deng Wei, Dai Erfu, Jia Yangwen et al., 2015. Spatiotemporal coupling characteristics, effects and their regulation of water and soil elements in mountainous area. Mountain Research, 33(5): 513-520. (in Chinese)

Deng Wei, Tang Wei, 2013. General directions and countermeasures for urbanization development in mountain areas of China. Mountain Research, 31(2): 168-173. (in Chinese)

Ersbøll A K, Ersbøll B K, 2009. Simulation of the K-function in the analysis of spatial clustering for non-randomly distributed locations: Exemplified by Bovine Virus Diarrhoea Virus (BVDV) infection in Denmark. Preventive Veterinary Medicine, 91(1): 64-71.

Faludi A, 2009. A turning point in the development of European spatial planning? The 'Territorial Agenda of the European Union' and the 'First Action Programme'. Progress in Planning, 71(1): 1-42.

Fan Jie, Zhou Kan, Sun Wei et al., 2013. Scientific values and research innovations of human-economic geography in construction of ecological civilization. Progress in Geography, 32(2): 147-160. (in Chinese)

Fang Zhongquan, Ding Sibao, 2008. Principal function area division and innovation of regional planning in China. Scientia Geographica Sinica, 28(4): 483-487. (in Chinese)

Fleskens L, Duarte F, Eicher I, 2009. A conceptual framework for the assessment of multiple functions of 
agro-ecosystems: A case study of Tra's-os-Montes olive grove. Journal of Rural Studies, 25(1): 141-155.

Huang Jinchuan, Li Haoxi, Qi Xiaoxiao, 2017. A literature review on optimization of spatial development pattern based on ecological-production-living space. Progress in Geography, 36(3): 378-391. (in Chinese)

Huo Renlong, Yang Yida, Man Zhimin, 2016. Pattern evolution of settlement space in the Zhangjiuhe Basin, Yunnan province, during the past 300 years. Geographical Research, 35(9): 1647-1658. (in Chinese)

Jansky L, Ives J D, Furuyashiki K et al., 2002. Global mountain research for sustainable development. Global Environmental Change, 12: 231-239.

Kates R W, Clark W C, Corell R et al., 2001. Environment and development: Sustainability science. Science, 292(5517): 641.

Li Guangdong, Fang Chuanglin, 2016. Quantitative function identification and analysis of urban ecological-production-living spaces. Acta Geographica Sinica, 71(1): 49-65. (in Chinese)

Li Xia, Ye Jiaan, 1997. Application of remote sensing for monitoring and analysis of urban expansion: A case study of Dongguan. Geographical Research, 16(4): 56-62. (in Chinese)

Li Zongxing, He Yuanqing, Xin Huijuan et al., 2010. Spatio-temporal variations of temperature and precipitation in Mts. Hengduan region during 1960-2008. Acta Geographica Sinica, 65(5): 563-579. (in Chinese)

Liu Jiyuan, Zhang Zengxiang, Xu Xinliang et al., 2010. Spatial patterns and driving forces of land use change in China during the early 21st century. Journal of Geographical Sciences, 20(4): 483-494.

Liu Pei, Duan Jiannan, Wang Wei et al., 2010. Study on systems of the land-use system functional classification and evaluation. Journal of Hunan Agricultural University, 36(1): 113-118. (in Chinese)

Ma Keming, Fu Bojie, 2000. Landscape pattern and fragmentation in Donglingshan Montane Region. Acta Phytoecologica Sinica, 24(3): 320-326. (in Chinese)

Ma Shifa, Ma Mei, Cai Yumei et al., 2015. Delimitating red line of ecological protection for territorial spatial planning: A case study of Hunan Province. Tropical Geography, 35(1): 43-50. (in Chinese)

Marsden T, Sonnino R, 2008. Rural development and the regional state: denying multifunctional agriculture in the UK. Journal of Rural Study, 24: 422-431.

Pelucha M, Kveton V, Jilkova J, 2013. Territorial dimensions of agro-environmental measures and LFA in rural development policy in the Czech Republic. Land Use Policy, 34(1): 91-103.

Peng Jian, Wang Yanglin, Zhang Yuan et al., 2006. Research on the influence of land use classification on landscape metrics. Acta Geographica Sinica, 61(2): 157-168. (in Chinese)

Wang Jinliang, Shao Jingan, Li Yangbing, 2014. On the Expansion Characteristics of Clustered Cities in the Mountainous Metropolitan Area and Their Spatial Distribution Trend. Journal of Southwest University (Natural Science Edition), (12): 122-127. (in Chinese)

Xi Jianchao, Wang Shoukun, Zhang Ruiying, 2016. Restructuring and optimizing production-living-ecology space in rural settlements: A case study of Gougezhuang Village at Yesanpo Tourism Attraction in Hebei Province. Journal of Natural Resources, 31(3): 425-435. (in Chinese)

Zeng Yongnian, He Lili, Jin Wenping et al., 2012. Quantitative analysis of the urban expansion models in Changsha-Zhuzhou-Xiangtan metropolitan areas. Scientia Geographica Sinica, 32(5): 544-549. (in Chinese)

Zhang Bailin, Cai Weimin, Zhang Fengrong et al., 2016. Spatio-temporal evolution of rural settlements and its driving forces in Yishui county, Shandong province from Sui dynasty to 1949. Economic Geography, 35(6): 1141-1150. (in Chinese)

Zhang Hongqi, Xu Erqi, Zhu Huiyi, 2015. An ecological-living-industrial land classification system and its spatial distribution in China. Resources Science, 37(7): 1332-1338. (in Chinese)

Zhao Yuan, Yang Zuying, Hao Lisha et al., 2012. The evolution of spatial displacement pattern of China's crude oil flow source-sink system. Acta Geographica Sinica, 67(4): 25-36. (in Chinese)

Zhou Baotong, 2004. Study on basic theoretical concepts of sustainable land use. Journal of Southwest China Normal University, 29(2): 310-314. (in Chinese)

Zhou Nianxing, Huang Zhenfang, Jiang Mingping et al., 2012. The relationships between forest landscape visual quality and landscape spatial pattern index of Mount Lushan. Geographical Research, 31(7): 1224-1232. (in Chinese) 